\title{
The Construction of Biopsychosocial Concept On Video On Demand Technology in Raising Empathy and Improving Communication of Counselor Candidates
}

\author{
Henny Indreswaria ${ }^{a}$, Henry Praherdhiono ${ }^{b}$ \\ Malang State University \\ Corresponding e-mail: ahenny.indreswari.fip@um.ac.id
}

\begin{abstract}
A biopsychosocial approach to the concept of empowering empathy and communication is the idea of strengthening the competence and capability of the counselor. Strengthening the counselor capability is the counselor's capacity in linking interactions and actions with various biological factors. Strengthening the counselor competence is the ability of counselors to link interactions and actions with psychological and social factors. The concept of strengthening the competencies and capabilities formed are used as the principles of constructing video video on demand technology, as a message design in learning. Video video on demand technology is the motivation for empathetic skills and Literacy of communication skills for counselor candidates. The biopsychosocial approach can also be a way of identifying counselees' problems. The study of biopsychosocial conceptual has three categories. 1) conceptual review, 2) principles of development. 3) study on video on demand implementation in the learning process
\end{abstract}

Keywords: biopsychosocial, competence, capability, counselor

\section{INTRODICTION}

Learning innovations are underway to face the 21 st century learning era. On demand learning, a powerful learning design with innovative design, is considered as an efficient and effective way to assist in student learning (Martin \& Foetschl, 2016; Perez, 2016; Wang, Guo, \& Chen, 2016). Given this potential, there has been a concerted effort to produce multimedia devices with designs for strengthening pedagogy and possessing sound graphic and technical sound design (RE Mayer, 2009; Richard E. Mayer, Heiser, \& Lonn, 2001; Richard E. Mayer \& Moreno , 2003). In addition, an evaluation to improve and enhance multimedia in the field of learning during development is necessary (Basitere \& Ndeto Ivala, 2017 Bogdanović, Barać, Jovanić, Popović, \& Radenković, 2014; Damala, Cubaud, Bationo, Houlier, \& Marchal, 2008). There is a number of advantages gained from the results of sharing evaluation, which are 1) saving time in development and revision, 2) optimizing the potential for developing pedagogy, graphics, and sound; and 3) providing a logical learning structure, integrative impact or evaluation.

Research conducted in Guidance and Counseling Department Department requires the development in the field of study. Research on the development in the field of empathy studies needs expanding on the explanation of detailed learning objectives, especially in the context of education and design use for 1) multimedia in counseling learning, 2) communication with counselees. The learning implementation is merely in the education process of prospective counselors, and its emphasis on the aspects of knowledge and counseling skills. A variety of researchoriented cultivation on prospective counselor, in principle, needs no preparation and embed of the ownership knowledge, attitudes, and skills in the implementation of basic attitudes or affective aspects (Ivey \& Daniels, 2016; Cyril et al., 2017). Thus, it is necessary to have learning implementation that refers to an implemented understanding oriented in the core conditions of counseling that must be mastered, such as empathy, genuineness, congruence, unconditional positive regard; in order to establish the balance in cognition, effectiveness, and skills (Seels \& Richey, 1994). In the implementation step, affective aspects include the aspect of attitude, and the nature of less motivation in learning. The affective aspect is poorly developed. It can even be said as slightly neglected. The personality competence of the counselor 
actually covers the field of work which refers to the attitude and nature of the counselor that underlies the daily performance of a counselor (Indreswari, 2015). Lack of attention to the affective aspects is what seems to spur the habit of less communicative counselor.

Empathy that is illustrated by the attitude and behavior of some students majoring in Guidance and Counseling Department is generally still not stable. Empathy has been recognized as the foundation of a very special relationship (Bayne \& Jangha, 2016; Leppma \& Young, 2016; MacDonald \& Price, 2017) . Research specifically finds counselor candidates often start their activities with idealism, so a number of studies has proven a diminish in empathy at the end of the learning period (Hojat, 2016). There are many strategies to teach empathy to students. These strategies addresses various aspects of empathy-emotive, moral, cognition, and learning behaviors that are performed with interpersonal skills, audio and video recordings.

The condition of prospective counselor pictures the condition of the counselor. Grounded on the information obtained from the counselor who are also participants of Pendidikan dan Latihan Profesi Guru (PLPG) Guidance and Counseling Department Rayon 15 State University of Malang (Universitas Negeri Malang), as well as observations and interviews that are conducted intensely, there are facts that state the performance of daily life counselor in schools are quite diverse in implementing empathy as the embodiment of their personality competencies. From the observation results in the beginning of counseling practice at the PLPG activities, it can be identified that most counselors showed "rigidity" in dealing with counselees. It is observed through the attitude of the interviewers that counseling counselors tend to be interrogative and immediately act as advisors that then give the impression of wanting to end to the counseling process immediately (Indreswari, 2015). This condition is far from the condition that should be shown by a counselor, lover handle the konselinya through counseling process. 2015 ). The condition is far from the condition that should be shown by a counselor, lover handle the konselinya through counseling process. The condition is far from the attitude that should be shown by a counselor in handling their counselees in counseling process.

Being prospective counselors requires complex knowledge. Identifying counselee problems in clinical interviews is a complex skill (Hall, Staiger, Simpson, Best, \& Lubman, 2016; Ignacio et al., 2016; Silverman, Kurtz, \& Draper, 2016). Counselors should not ignore the biological aspects (face pain, fatigue, illness etc.), and social factors, or just pay attention to the psychological domain alone, Counselors' attention is addressed to all aspects that the counselees experience. If this condition is shown by the counselor, it then can give a very significant contribution to the counselee problem. This condition is needed in the empathy implementation. Empathy in communicating with counselee, in general, aims to remind students to consider all aspects in the history of integrated counseling through biopsychosocial approach.

The ability of clinical interviews in interpersonal interaction can be referred to as micro communication skills. These micro skills refer to the interview strategies, which is used to facilitate the success of the interview, and to establish the relationship between interviewers and interviewees (Ivey \& Daniels, 2016). Micro skills include both verbal and non-verbal skills. Verbal strategies include using different types of questions (open, closed or prominent); reflecting, and paraphrasing minimal encourage; and using different tones (Ivey \& Daniels, 2016). Nonverbal strategies include posture and facial expressions, and encourages such as nods and eye contact (Stickley, 2011). A counselor that is skilled in listening to the verbal responses can properly observe the behavior of nonverbal counselees. They will also be able to monitor the "comfort" felt by a counselee, and thus the counselor can develop the interviews into appropriate and warm interviews.

\section{VIDEO ON DEMAND TECHNOLOGY IN THE EMPATHY CAPABILITY}

The condition of the counselor candidates is also not much different from the counselors. The condition of the counselor candidates also leads to a low of the empathy level. The finding of this research refers to the attitude of the prospective counselor of the undergraduate students of Guidance and Counseling Department major class 2006. It shows that students feel that the teaching and learning processes contain more cognitive aspects, and ignore the aspect of attitudes, moral values, and psychomotor aspects 
(Hidayah, 2009). This teaching and learning process that contains affective aspects (empathy, respect for diversity, personal intelligence) are neglected in the learning design. This condition informs that further study is necessary.

In the context of the counselor candidates' preparation, which is oriented with the embed and development of affective aspects, as the counselors' core condition, namely genuineness or congruence, unconditional positive regard, empathy, needs to be conducted. The implementation of counselor's basic attitudes is necessary to serve as a competent counselor, capable of demonstrating genuineness, unconditional positive regard, and empathic attitudes (Wedding 2010, Indreswari, 2015). Basic attitudes are needed so that counselors can enter the "counselee world" when the counsellors face the counselee in the helping process. The focus of this idea is one of the basic attitudes, namely empathy coupled with micro skills. To make empathetic counselors, a certain strategy is necessary in the process of embedding their mastery. Furthermore, empathy learning by using micro skills and on demand media is pursued through Learning Partnership Model (LPM) (Indreswari, 2015) . Namely empathy coupled with micro skill. To make this empathy into the counselors, a certain strategy is needed in the process of embedding their mastery. Furthermore, empathy learning by using micro skill through on demand media is pursued through Learning Partnership Model (LPM) (Indreswari, 2015).

Video on demand technology is a type of classroom intervention that has been developed to help learners in viewing artificial conditions and has been successfully used in various circumstances (Schmid et al., 2014; Schmidt \& Bonds-Raacke, 2013). Prospective education counselor should be introduced to the modification of video on demand technology in the form of fact presentation with themes that may be able to provoke empathy. In general, video on demand technology in LPM is a tool for achieving empathy for prospective education counselors to be able to develop attitude aspects in a lesson.

Many studies favor video on demand technology. This kind of research is generally conducted to the learners who are still difficult to view abstract condition (Schmid et al., 2014; Schmidt \& Bonds-Raacke, 2013). This study analyzes the effects of video on demand technology to help actualize the actual conditions. This study has a particular focus on improving learning behavior and involvement in learning. The results show that there is a change in behavior, and it increases significantly compared to other learners who are treated as control groups. These changes include improvements in learning and learning skills.

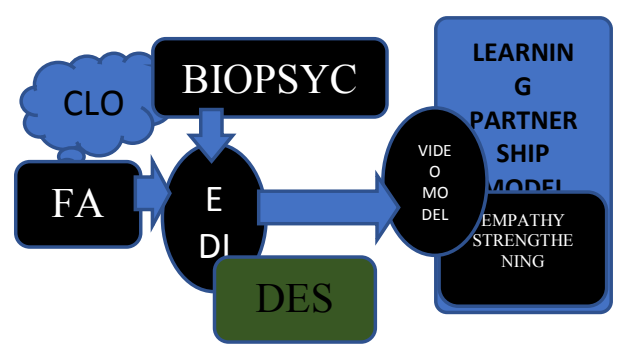

Figure 1. The Construction of empathy empowerment using on demand video

Video on demand technology is a modified technology for prospective counselors. Although the potential counselor will be emotionally attached to the real fact, they must have learning experiences in the use of video on demand technology for learning and learning necessity. Prospective counselors will be able to develop empathy and have a positive attitude in channeling and expressing counseling activities on the counselees.

The implementation of on demand learning technology in teaching and learning can be categorized as a simple and realistic academic activity. Video on demand technology does not require a video recording device with a class of professional broadcast (Gernsbacher, 2015; Martin \& Foetschl, 2016). Video on demand technology requires only minimalist software and hardware. The general overview of video on demand technology applied in this paper is a technology that is able to present the fact video and assisted by personal computer that has the specified operating system. Video on demand technology is also a video assisted by software that has the capabilities and specifications of the video player in the computer.

\section{THE BIOPSYCHOSOCIAL DESIGN AND CONTENT AS MICRO SKILL}

Learning in designed counseling is an activity for students to construct how counselors play a role in an interview. As a 
prospective counselor student, it is necessary for them to be given a number of choices regarding types of questions that reflect the different conditions of micro skills. Students need learning experiences from various sources in terms of questioning techniques and everything related to biopsychosocial counselees (Chen, Lambert, \& Guidry, 2010). By fact videos, students can see the consequences and implications of asking different question when the counselors listen to and observe the responses of the counselee. In particular, students are guided by lecturers to be consistent with the concepts and processes of good counseling interview.

Video on demand technology is employed to help prospective counselor candidates, to be able to give reflection, questions specific to audio-video segment on the screen, and the students can answer various problems from the counselees (Wang et al., 2016). Students will be encouraged to give response to what they notice about the counselees in the video models, both verbal and non-verbal. The students then are challenged to think about the direction to where the counseling interviews are heading. In addition to consider the micro skills that are reflected in the student's choices, students are asked to reflect on the possible causes of the counselees' main complaints. This process aims to improve students' understanding of the biopsychosocial aspect as counselee problems.

The use of video on demand technology sees a number of advantages in developing empathetic counselors. First, the evaluation is not only for students to participate in interviews with counselees, but also to evaluate students in constructing and controlling the cognitive aspects and direction of counseling interviews constructed from biopsychosocial interview techniques. Each student can choose questions, choices, and paths in a reasonable interview. By interacting through video on demand technology videos, the students are expected to establish a new understanding of the content area based on their knowledge of appropriate counseling interview methods.

One important challenge faced by teachers is to enable passive learners to utilize more active approaches to learn and construct new knowledge (Kennedy \& McNaught, 1997). Communicating with counselees aims to face challenges and engaging students in the learning experience provide not only information for students.
Theoretically, this method is consistent with the constructivist philosophy.

Micro skills in the form of biopsychosocial interview techniques encourage the integration of diagnosis and treat challenging behaviors. Biopsychosocial interview techniques using video on demand technology represent integrative negative approach in diagnosis. Challenging behavior is non-specific symptoms associated with controlling influence and remained so until a thorough assessment has been completed toward the conditions that affect the counselees' severity, variability, and resilience. The assessment will include a careful analysis of biomedical potential, socio-environmental and psychological factors that affect behaviors, and influence each of these factors (Ryan, Virani, \& Austin, 2015). The biopsychosocial interview techniques provide the necessary basis for lowering excessive interventions to counselors and will be based on more diagnosis(Corey, 2015).

As a comparison, biopsychosocial interview techniques have succeeded in assisting a single hypothesis, e.g. psychopharmacology, behaviours (Anisman, 2012). There is also a linear application of these techniques, e.g. medical, psychopharmacology, and behaviour (Wilson \& Jefferson, 1985). Thus, assessment and intervention efforts of biopsychosocial interview techniques are required by prospective counsellors. The link of biopsychosocial interview techniques to empathetic reinforcement occurs dynamically from factors that affect behaviours. Empathy empowerment needs to be strengthened as a standard of ability (competence) as well as innovative ability to create interview techniques based on biopsychosociall. Counselees, prior the interview, actually can have a medical diagnosis, but the accuracy of the diagnosis still requires other skills such as psychology and the understanding of the social conditions of the counselees. Poorhandled counselees are predicted to get bigger problems. This condition can lead to more complex disorders (Corey, 2015, Gardner, 1998).

\section{CONCLUSION}

The biopsychosocial approach in the form of biopsychosocial interview techniques is an attempt to strengthen the prospective counselors' empathy and communication 
ability which are the idea of strengthening the competence and counselor capability. The capability of strengthened counselors is the counselors' capacity to link interactions and actions to the biological factors that vary with the psychological conditions in everyday life. The counselors' competence that is strengthened counselor is a counselors' ability to empathize by linking the biological conditions of the counselees in certain levels such as their psychological and social condition.

The concept of strengthening the counselors' empathy is actually located in their competence (ability standard) and capability (established student ability) (Cleary et al., 2017; McLean, Feather, \& Butler-Jones, 2011). The concept is created and used as the principles of empowering empathy through video on demand technology that is a teaching delivery technology. Online based video on demand technology will be a model video to provide motivation for empathy and communication skills for prospective literacy counselors. A biopsychosocial approach can also be used as a way to identify counselees' problems. Biopsychosocial conceptual studies included as interview techniques have three categories of impressions. The video on demand biopsychosocial content includes 1) the evaluation consisting of conceptual biopsychosocial reviews, 2) study and implementation of video on demand technology in the learning process 3) the technical principles of both formal and informal interviews by lecturers.

\section{REFERENCE}

[1] Anisman, H. (2012). Psychopharmacology of aversively motivated behavior. Springer Science \& Business Media.

[2] Basitere, M., \& Ndeto Ivala, E. (2017). An Evaluation of the Effectiveness of the Use of Multimedia and Wiley plus WebBased Homework System in Enhancing Learning in the Chemical Engineering Extended Curriculum Program Physics Course. Electronic Journal of E-Learning , 15 (2), 156-173.

[3] Bayne, HB, \& Jangha, A. (2016). Utilizing Improvisation to Teach Empathy Skills in Counselor Education. Counselor Education and Supervision, 55 (4), 250-262.
[4] Bogdanović, Z., Barać, D., Jovanić, B., Popović, S., \& Radenković, B. (2014). Evaluation of mobile assessment in a learning management system. British Journal of Educational Technology , 45(2), 231-244.

[5] Chen, P.-SD, Lambert, AD, \& Guidry, KR (2010). Engaging online learners: The impact of Web-based learning technology on college student engagement. Computers \& Education , 54 (4), 12221232.

[6] Cleary, MN, Wozniak, K., Marienau, C., Wilbur, G., Tolliver, DE, \& Meyer, P. (2017). Learning, Adults, and Competency-Based Education. In Handbook of Research on CompetencyBased Education in University Settings (pp. 210-231). IGI Global.

[7] Corey, G. (2015). Theory and practice of counseling and psychotherapy. Nelson Education.

[8] Damala, A., Cubaud, P., Bationo, A., Houlier, P., \& Marchal, I. (2008). Bridging the gap between the digital and the physical: design and evaluation of a mobile augmented reality guide for the museum visit. In Proceedings of the $3 \mathrm{rd}$ international conference on Digital Interactive Media in Entertainment and Arts (pp. 120-127). ACM.

[9] Gardner, H. (1998). A Reply to Perry D. Klein's "Multiplying the Problems of Intelligence by Eight." Canadian Journal of Education / Revue Canadienne de L'éducation , 23 (1), 96-102.

[10] Gernsbacher, MA (2015). Video captions benefit everyone. Policy Insights from the Behavioral and Brain Sciences , 2 (1), 195-202.

[11] Hall, K., Staiger, PK, Simpson, A., Best, D., \& Lubman, DI (2016). After 30 years of dissemination, have we achieved sustained practice change in motivational interviewing? Addiction , 111(7), 11441150.

[12] Hidayah, N. (2009). Process-Audit in the Provision of Academic Education level S1 Guidance and Counseling Department (Dissertation). DISERTATION AND TESIS Graduate Program UM .

[13] Hojat, M. (2016). Empathy and Gender: Are Men and Women Complementary or Opposite Sexes? In Empathy in Health Professions Education and Patient Care (pp. 169-187). Springer.

[14] Ignacio, J., Dolmans, D., Scherpbier, A., Rethans, J.- J., Lopez, V., \& Liaw, SY 
(2016). Development, implementation, and evaluation of a mental rehearsal strategy to improve clinical performance and reduce stress: A mixed methods study. Nurse Education Today , 37 , 2732.

[15] Indreswari, H enny . (2015). Effectiveness of Partnership Model in Learning to Improve Empathy Candidate Candidate Ability. Dissertation. Postgraduate Masters .

[16]Ivey, AE, \& Daniels, T. (2016). Systematic interviewing microskills and neuroscience: Developing bridges between the fields of communication and counseling psychology. International Journal of Listening , 30 (3), 99-119.

[17] Kennedy, D., \& McNaught, C. (1997). Use of concept mapping in the design of learning tools for interactive multimedia. Journal of Interactive Learning Research , 8 (3), 389.

[18]Leppma, M., \& Young, ME (2016). Loving - Kindness Meditation and Empathy: A Wellness Group Intervention for Counseling Students. Journal of Counseling \& Development, 94 (3), 297305.

[19] MacDonald, HZ, \& Price, JL (2017). Emotional Understanding: Examining Alexithymia as a Mediator of the Relationship Between Mindfulness and Empathy. Mindfulness, 1-9.

[20]Martin, A., \& Foetschl, H.-P. (2016). Video-on-demand system . Google Patents.

[21] Mayer, RE (2009). Multimedia learning 2nd $E d$. New York: Cambridge University Press.

[22] Mayer, Richard E., Heiser, J., \& Lonn, S. (2001). Cognitive constraints on multimedia learning: When presenting more material results in less understanding. Journal of Educational Psychology, 93 (1), 187.

[23] Mayer, Richard E., \& Moreno, R. (2003). Nine ways to reduce cognitive load in multimedia learning. Educational Psychologist , 38 (1), 43-52.

[24] McLean, S., Feather, J., \& Butler-Jones, D. (2011). Building health promotion capacity: action for learning, learning from action. UBC Press.
[25]Perez, MD (2016). Video-on-demand content delivery system for providing video-on-demand services to $T V$ service subscribers . Google Patents.

[26] Ryan, J., Virani, A., \& Austin, JC (2015). Ethical issues associated with genetic counseling in the context of adolescent psychiatry. Applied \& Translational Genomics , 5 , 23-29.

[27] Schmid, RF, Bernard, RM, Borokhovski, E., Tamim, RM, Abrami, PC, Surkes, MA, ... Woods, J. (2014). The effects of technology use in postsecondary education: A meta-analysis of classroom applications. Computers \& Education , 72 , 271-291.

[28] Schmidt, C., \& Bonds-Raacke, J. (2013). The Effects of Self-Modeling Video on Children with Autism Spectrum Disorder. International Journal of Special Education , 28 (2), 136-146.

[29] Seels, B., \& Richey, RC (1994). Instructional technology. Bloomington, IN: Association for Educational Communications and Technology .

[30] Silverman, J., Kurtz, S., \& Draper, J. (2016). Skills for communicating with patients. CRC Press.

[31] Siril, H., Fawzi, MCS, Todd, J., Wyatt, M., Kilewo, J., Ware, N., \& Kaaya, S. (2017). Hopefulness fosters affective and cognitive constructs for actions to cope and enhance the quality of life among people living with HIV in Dar Es Salaam, Tanzania. Journal of the International Association of Providers of AIDS Care (JIAPAC) , 16 (2), 140-148.

[32] Stickley, T. (2011). From SOLER to SURETY for effective non-verbal communication. Nurse Education in Practice, 11 (6), 395-398.

[33] Wang, Y., Guo, Y., \& Chen, Y. (2016). Accurate and early prediction of user lifespan in an online video-on-demand system. In Signal Processing (ICSP), 2016 IEEE 13th International Conference on (pp. 969-974). IEEE.

[34] Wedding, D. (2010). Current psychotherapies. Wiley Online Library.

[35] Wilson, WH, \& Jefferson, JW (1985). Thyroid disease, behavior, and psychopharmacology. Psychosomatics, 26 (6), 481-492. 